bahasa \& sastra, Vol. 14, No.2, Oktober 2014

\title{
EVALUATION OF A HOTEL MANAGEMENT TEXTBOOK BASED ON WORLD LANGUAGE STANDARDS
}

\author{
Kun Aniroh \\ Diploma IV Tourism Program, Merdeka University Malang \\ E-mail: kun.aniroh@gmail.com
}

\begin{abstract}
The aim of this study is to evaluate, using world language standards 2007, a textbook on hotel management and tourism for intermediate to advanced level students. The respondents of this study were two groups: experts and students. The experts include English lecturers at hotel department and hotel supervisors. The students include hotel and tourism students. The respondent come from 5 (five) higher tourism colleges. The study utilized the questionnaire developed on World Language Standards 2007, consisting of fifty three indicators that follow: content, exercises, communication, cultures, connections, communities and general elements. A continuous scoring procedure was used in which 1 was for the minimum and 4 was the maximum score. The results revealed these points: Of the ten indicators of general elements the highest score from the students the rated score reached 3.17 points of 4 . Of the eleven content indicators of the experts the rated score reached 3.37 points and the score reached 3.36 points for the seven indicators of the exercise. The score of the communication consisting of eleven indicators reached 3.23 points, and of the six indicators of cultures the scored reached at 3.52 points. The next is the score of the connection consisting of three indicators reached at 3.63 points, the communities consisting of five indicators the score reached at 3.68 points and the last is general elements consisting of ten indicators the rated score reached 3.36 points. The findings showed that the score of the all variables were above three meaning that it is considered good. However, the textbook still needed improving if it will be published as a course book as it was suggested by the students and the experts.
\end{abstract}

Keywords: hotel management materials, world language standards, students, experts, betterment

\begin{abstract}
Abstrak
Tujuan dari penelitian ini adalah untuk mengevaluasisebuah buku tentang manajemen hotel dan pariwisata untuk mahasiswa tingkat menengah dan mahir, dengan menggunakan standar bahasa dunia tahun 2007.Responden dari penelitian ini adalah dua kelompok: para ahli dan mahasiswa. Para ahli terdiri dari dosen bahasa Inggris di Jurusan Perhotelan dan para supervisor hotel. Responden mahasiswa terdiri dari mahasiswa jurusan hotel dan pariwisata. Responden berasal dari lima sekolah tinggi pariwisata. Penelitian ini menggunakan kuesioner yang dikembangkan berdasarkan Standar Bahasa Dunia 2007, yang terdiri dari 53 indikator yang meliputi isi, latihan, komunikasi, budaya, hubungan, masyarakat dan elemen umum. Prosedur skor
\end{abstract}


continuous digunakan di mana 1 untuk skor minimum dan 4 skor maksimum. Hasil penelitian menunjukkan beberapa hal berikut. Dari sepuluh indikator elemen umum, nilai tertinggi mahasiswa mencapai 3.17 dari total 4. Dari sebelas indikator isi dari para ahli, nilai mencapai 3,37 dan 3,36 untuk tujuh indikator latihan. Nilai komunikasi yang terdiri dari sebelas indikator mencapai 3,23.Dari enam indikator budaya,nilai yang dicapai adalah 3,52. Yang berikutnya adalah nilai hubungan yang terdiri dari tiga indikator yang mencapai 3,63, nilai masyarakat yang terdiri dari lima indikator skor mencapai 3,68 dan yang terakhir adalah elemen umum yang terdiri dari sepuluh indikator yang mencapai nilai 3,36. Temuan ini menunjukkan bahwa nilai dari semua variabel berada di atas 3, artinya dianggap baik. Namun, buku ini masih perlu ditingkatkan jika akan diterbitkan sebagai buku kursus seperti yang disarankan oleh para mahasiswa dan para ahli.

Kata-kata kunci: bahan manajemen hotel, standar bahasa dunia, mahasiswa, ahli, perbaikan.

\section{INTRODUCTION}

Preparing materials for the students of hotel management and tourism in the intermediate to advanced levels is a challenging activity. Casual observations show the fact that most English lecturers who teach at hotel departments have limited, not to say absence of, background of the knowledge of the hotel world. The ideal English lecturer who teaches English for Hotel (hereafter, $E F H$ ) has the interest or is willing to learn about hotel matters, to learn with subject specialists, has time to do that, and has the support from the stakeholders in writing and developing EFH materials. This is of a great concern in $E F H$ as a matter of fact that $E F H$ lecturers face the very few materials dealing with hotes matters whether it is in the form of course books or materials written by the lecturers. Sierocka (2012) states that the constraints of materials writing are among others time avaliability, financial supports, the writer's self-efficacy, and the absence of the cooperation between
English lecturers and subject-matter specialists.

The development of hotel industries in the global era requires the good qualifications of the graduates not only in the craft but also the supervisory and the managerial levels, too. Since 2008, the ASEAN market for the hotel human resources set the minimum requirement of Diploma IV graduates for some positions with the good service personality attributes and English (Kompas, March 2008). Competencybased standards for hotel professions published a guidance for hotel professions in 1999 for the craft to the managerial levels to anticipate the global world demands. Education institutions of hotel and tourism then mapped the curriculum in which competency-based standards constitute an important point in developing a relevant curriculum. This will have the impact in preparing $E F H$ materials for the students. As has been mentioned previously, the lack of the domestic materials and the course book makes the English lecturers feel unconfident. There are though 
possibilities of purchasing $E F H$ materials in the market. But, the materials available in the market do not sufficiently address the needs of the students in learning English and contents in the $E F H$ contexts. The requirements of the tourism industries as the users and the lack of the $E F H$ materials in the hotel department are two important concerns which have to be solved out properly if anticipating global competitions in hotel management becomes the vision. Considering these, therefore, a part of solving the problems is to develop relevant and suitable $E F H$ materials.

There are several key principles for designing language teaching materials. These principles are derived from recent theory, research and practice in language learning and teaching (Aniroh, 2009). According to Nunan (1988:1), the principles are as follows. First, materials should be clearly linked to the curriculum they serve. Next, materials should be authentic in terms of text and task. Then, materials should stimulate interaction and materials should allow learners to focus on formal aspects of the languages. Also, materials should encourage learners to develop skills, and skills in learning-how-tolearn. Finally, materials should encourage learners to apply their developing language skills to the world beyond the classroom

As observed by Aniroh (2009), good textbooks are those that make learners learn effectively. However, how good they are good seems a matter of delicate views. This is reflected by the presence of several criteria proposed by different people. All are equally important and at the same time all are equally posed with potential challenges for a textbook to cater for at once.
Crawford (2002), for example, suggests several points for textbooks in order to become an effective vehicle during the teaching learning process. Some of her views, however, are rather elusive. Some important points are worth presenting. In the first place, textbooks necessarily contextualize the language that they stand for. Language does not exist in vacuum. It has social context of use. This is such contextualizing functions that a textbook needs to represent. Next, textbooks need to focus on whole-text levels of language. This implies that meaning on language use is of primary concern. Authenticity and being realistic are another characteristic that a textbook should hold, in that the characteristic needs to provide a room for learners to explore to produce authentic language. In addition, language materials could do with a strong basis on which learners individualize their learning. Effective textbooks necessarily enhance autonomous learning on the part of the learners. In a whole-class context, individual differences are inevitable. It is therefore in these usual situations that textbooks call for a quality for such mass accommodation. Finally, meaningful learning is the one in which learners can engage their cognitive and affective potentials. As such, effective materials are those that can make learners activate their resources.

Another view is succinct, straightforward, and readily applicable to textbook writing. This includes several criteria that are acronymized by Rajan (1997) as MAGIC, being motivating, meaningful; authentic, appropriate; graded; interesting, integrative (skills); and contextualized.

The EFH material to be evaluated in the present report is actually a textbook for $E F H$ students written as 
the result of a vast needs analysis involving visits to several international hotels in Indonesia, Japan, Malaysia, and Oman conducted by the writer. The needs assessment and needs analyses involved hotel managers, hotel supervisors and subject-matter specialists as well as students which were conducted by means of questionnaires, interviews, and observations on sites on contents of job descriptions and job analyses and language functions.

The results of the needs analysis were rich information on which to develop the textbook of $E F H$ focusing on integrated skills in which the priority skill is reading comprehension. The contents on hotel matters covered the job of hotel managers, the job of hotel supervisors, attitudes, the cultures, and other stuff having relation with the international career matters. Meanwhile, data on the language include language forms and language functions. Both content and language aspects based on the needs analysis were then used as a conceptual basis on which to develop an EFH textbook using the combined principles of the communicative approach, contextual teaching and learning, and problem based learning. The purpose of this study is to evaluate the textbook in terms of requirements of a good textbook as outlined by World Language Standards 2007.

\section{METHODS}

World Language Standards 2007 is a standard of textbook evaluation guide developed by Department of Education Indiana University and was adapted to evaluate the $E F H$ textbook developed in this present study. The elements in the questionnaire consist of content with eleven indicators, exercise seven indicators, in communication eleven indicators, cultures six indicators, connections three indicators, communities five indicators and general elements ten indicators. So, in total there are fifty three indicators are used to evaluate the textbook.

Prior to real administration of the questionnaire to the respondents, the questionnaire was tried out to 70 students and 9 raters. The results show that the inter-item reliability of the questionnaire was .957 at the Alpha coefficient analysis which means that there is evidence of high consistency among items in the questionnaire in generating scores. In addition, the interrater reliability using ANOVA Hoyt resulted in the $\mathrm{F}$ value $11.333(0.000)$ with the $r$ value of .769. This means that there was evidence of high consistency among raters in yielding scores. All these values indicate empirical evidence that the questionnaire was considered to be a good instrument to collect the data.

Upon the development of the textbook, the textbook was then tried out. In the tryout phase, there were 8 (eight) English lecturers and there are 63 (sixty three) students that were involved in the present study. These lecturers and students came from hotel management departments of six higher learning colleges: Trisakti University, Jakarta; Satyawidya Tourism College, Surabaya; Brawijaya University, Malang; State Polytechnique Banjarmasin; and Dianapura Tourism College, Denpasar, Bali. Originally there were 9 (nine) English lecturers involved in the present study. However, one English lecturer did not provide his feedback at the end of the try-out phase because he did not return the questionnaire without any explanation. Therefore, the respondents 
of the try-out phase mainly consist of only 8 (eight) English lecturers. In this try-out phase, in all, consequently, there are 8 (eight) English lecturers as the sources of data. They were to rate the textbook against the indicators of the following variables: 'Contents', 'Exercise', 'Communication', 'Cultures', 'Connections',
Communities', and 'General Elements' using a 4-scale measuring grid to reflect the quality of the textbook in these respects.

The criteria for evaluating the indicators of variables in a textbook are set up using the guideline outlined in Table 1 that follows.

Table 1. Guideline for Evaluating Indicators of the Textbook

\begin{tabular}{llll}
\hline Score & Score Range & Qualitative Description & Follow-up Actions \\
\hline 4 & $3.1-4.0$ & Very Good & No revision needed \\
3 & $2.1-3.0$ & Good & No revision needed \\
2 & $1.1-2.0$ & Sufficient & Possible revision needed \\
1 & $0.1-1.0$ & Bad & Revision badly needed \\
0 & 0 & Very Bad & Replacement needed \\
\hline
\end{tabular}

These lecturers taught their students in their regular classes using the textbook developed in the present study. The sixty three students taught by these lecturers constituted the data source in the present study. The questionnaire was then used as basis for evaluating the textbook by 8 (eight) English lecturers and 63 (sixty three) students as the data sources. The data collected were quantitative and qualitative. The data collected come from two sources of data as respondents, namely English lecturers who taught using the textbook and the students who were taught using the textbook. In addition, as a triangulating measure, the data were also collected from hotel supervisors. Unlike the data from English lecturers and students, the data collected from hotel supervisors are in the form of only qualitative ones. The data from lecturers, students, and hotel supervisors are presented separately. The quantitative data are the in the form of scores whereas the qualitative data take the form of evaluative criticisms, comments, suggestions, and notes.

\section{RESULTS AND DISCUSSION}

The results of data analyses are reported in three categories: presentation of the data collected from the English lecturers, those from students, and finally those from the supervisors. What follows is the presentation of the results.

Presentation of Quantitative Data Collected from the English Lecturers

The first variable to be rated of the book is variable 'contents'. In this variable, there are 11 (eleven) indicators. As shown by the name, these 11 (eleven) indicators reflect how the content of the textbook is organized. The result of the data analysis is presented in Table 2 . 
Table 2. 'Contents' of the Textbook Rated by Eight Independent English Lecturers

\begin{tabular}{|c|c|c|c|c|c|c|c|c|c|c|}
\hline \multirow{2}{*}{ Indicators } & \multicolumn{10}{|c|}{ Lecturers' Scores } \\
\hline & 1 & 2 & 3 & 4 & 5 & 6 & 7 & 8 & Total & Mean \\
\hline $\begin{array}{l}\text { The contents are presented either topically or } \\
\text { functionally in a logical, organized manner }\end{array}$ & 4 & 4 & 3 & 4 & 3 & 4 & 4 & 4 & 30 & 3.75 \\
\hline $\begin{array}{l}\text { The content serves as a window into further } \\
\text { learning about the intended areas i.e. hotel } \\
\text { management and hospitality industries }\end{array}$ & 3 & 4 & 4 & 4 & 3 & 4 & 4 & 4 & 30 & 3.75 \\
\hline $\begin{array}{l}\text { The reading selections are authentic pieces of } \\
\text { language }\end{array}$ & 2 & 4 & 2 & 4 & 3 & 4 & 4 & 4 & 27 & 3.40 \\
\hline $\begin{array}{l}\text { The content contains real-life issues that } \\
\text { challenge the learners to think critically about } \\
\text { hotel management and hospitality industries }\end{array}$ & 3 & 4 & 4 & 4 & 4 & 3 & 4 & 4 & 30 & 3.75 \\
\hline $\begin{array}{l}\text { The activities and lessons centered are on } \\
\text { real-world tasks and examples }\end{array}$ & 4 & 3 & 3 & 4 & 4 & 4 & 4 & 4 & 30 & 3.75 \\
\hline The layout is logical and clear & 3 & 4 & 2 & 2 & 3 & 2 & 4 & 2 & 22 & 2.75 \\
\hline $\begin{array}{l}\text { Learners can navigate the materials with } \\
\text { ease }\end{array}$ & 2 & 3 & 2 & 2 & 3 & 3 & 3 & 2 & 20 & 2.50 \\
\hline $\begin{array}{l}\text { The materials are both age- and } \\
\text { developmentally appropriate }\end{array}$ & 2 & 4 & 2 & 2 & 4 & 2 & 4 & 4 & 24 & 3.00 \\
\hline The content engages learners & 3 & 4 & 3 & 2 & 3 & 4 & 4 & 4 & 27 & 3.40 \\
\hline $\begin{array}{l}\text { The content builds upon prior knowledge and } \\
\text { provide opportunities for learners to expand } \\
\text { knowledge by emphasizing critical thinking } \\
\text { skills }\end{array}$ & 4 & 4 & 2 & 4 & 4 & 3 & 4 & 4 & 29 & 3.60 \\
\hline The information is current and accurate & 3 & 4 & 2 & 4 & 4 & 4 & 4 & 3 & 28 & 3.50 \\
\hline
\end{tabular}

As shown in Table 2, based on the mean value, out of 11 (eleven) indicators in variable 'contents', 4 (four) indicators $(36.36 \%)$ is rated at an averaged score of $3.75 ; 1$ (one) variable $(9.09 \%)$ reaches a score of 3.6 ; another 1 (one) variable $(9.09 \%)$ reaches a score of $3.5 ; 2$ (two) indicators $(18.18 \%$ ) are rated at an averaged score of 3.4; 1 (one) variable $(9.09 \%)$, gets a score of $3.00 ; 1$ (one) variable $(9.09 \%)$, gets a score of 2.75; and 1 (one) variable $(9.09 \%)$ is scored at 2.50, the lowest score. Visually, the data in variable 'contents' are presented in Figure 1.

\section{Histogram}

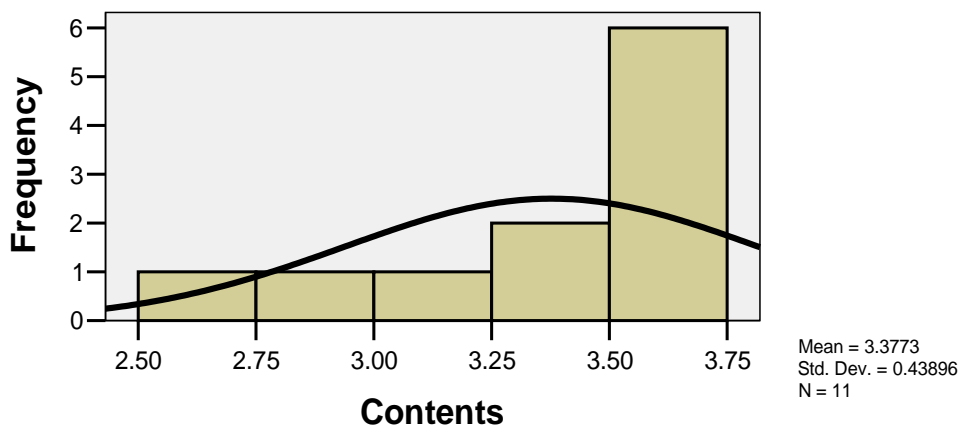

Figure 1. Mean on Variable 'Content' by the English Lecturers 
Based on Table 1 Guideline for Evaluating Indicators Reflecting the Textbook, the information in Table 2 reports that out of 11 indicators in variable 'content', each of the 9 indicators has a score figuring equal or greater than 2.50 , which is categorized as 'good'. The follow-up of this is that aspects of the textbook reflected in the indicators in variable 'content' need no revision according to the criteria or
Table 1 Guideline for Evaluating Indicators Reflecting the Textbook.

The second part of the textbook which needs to be evaluated is concerned with variable 'exercise'. This variable consists of 7 (seven) indicators, including, as its name indicates, matters related with exercises in the textbook to be rated. The result of the data collection is presented in Table 3 Evaluation on Variable 'Exercise' of the Textbook by the English Lecturers.

Table 3. 'Exercise' of the Textbook Rated by Eight English Lecturers

\begin{tabular}{|c|c|c|c|c|c|c|c|c|c|c|}
\hline \multirow[t]{2}{*}{ Indicators } & \multicolumn{10}{|c|}{ Lecturers' Scores } \\
\hline & 1 & 2 & 3 & 4 & 5 & 6 & 7 & 8 & Total & Mean \\
\hline $\begin{array}{l}\text { There are interactive and task-based } \\
\text { activities that require students to use } \\
\text { new vocabulary to communicate }\end{array}$ & 4 & 4 & 3 & 4 & 3 & 4 & 4 & 4 & 26 & 3.25 \\
\hline $\begin{array}{l}\text { The instructors in the textbook tell the } \\
\text { students to read for comprehension }\end{array}$ & 3 & 4 & 4 & 4 & 3 & 4 & 4 & 4 & 30 & 3.75 \\
\hline $\begin{array}{l}\text { Top-down and bottom - up strategies } \\
\text { are used }\end{array}$ & 2 & 4 & 2 & 4 & 3 & 4 & 4 & 4 & 27 & 3.40 \\
\hline $\begin{array}{l}\text { The students are given sufficient } \\
\text { examples to learn top-down } \\
\text { techniques for reading comprehension }\end{array}$ & 3 & 4 & 4 & 4 & 4 & 3 & 4 & 4 & 30 & 3.75 \\
\hline $\begin{array}{l}\text { The texts make comprehension easier } \\
\text { by addressing one new concept at a } \\
\text { time }\end{array}$ & 4 & 3 & 3 & 4 & 4 & 4 & 4 & 4 & 30 & 3.75 \\
\hline $\begin{array}{l}\text { The exercise promote critical thinking } \\
\text { of the text }\end{array}$ & 3 & 4 & 2 & 2 & 3 & 2 & 4 & 2 & 18 & 2.25 \\
\hline $\begin{array}{l}\text { The activities are enhanced by the } \\
\text { inclusion of authentic materials }\end{array}$ & 2 & 3 & 2 & 2 & 3 & 3 & 3 & 2 & 20 & 2.50 \\
\hline
\end{tabular}

As shown in Table 3, out of 7 (seven) indicators in variable 'exercise', the highest score is 3.75 reached in 3 (three) variables; whereas the lowest one is 2.25 reached in 1 (one) variable. More specifically, 3 (three) indicators
$(42.85 \%)$ is rated at an averaged score of 3.75; 4 (four) indicators are rated each at a score of $3.40(14.28 \%), 3.25$ $(14.28 \%), 2.50$ (14.28\%), and 2.25 $(14.28 \%)$ respectively. Visually the data 
in variable 'exercise' is presented in

Figure 2 as follows.

Histogram

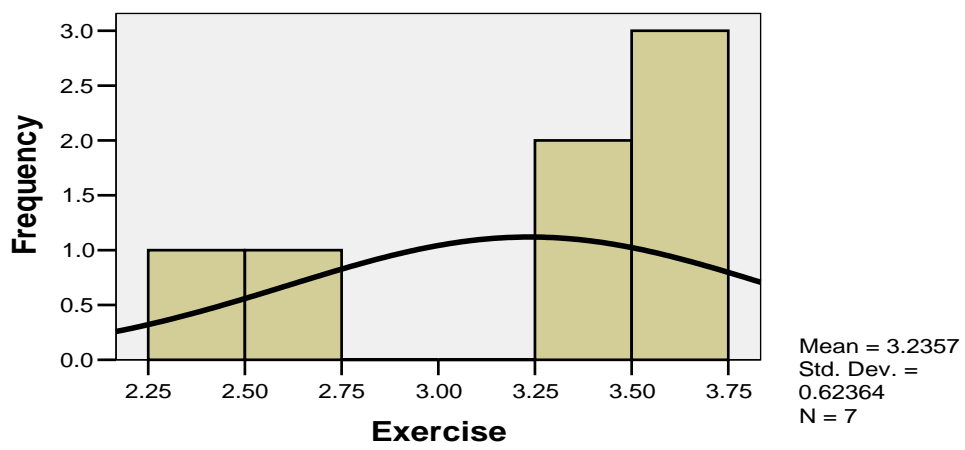

Figure 2. Data Distribution on Variable 'Exercise' by the English Lecturers

The information shown in Table 3 shows that the lowest score, which is 2.25 , is categorized as little above 'sufficient'; whereas the others are categorized as 'good' and 'very good' according to the criteria set up in Table 1 Guideline for Evaluating Indicators of the Textbook. In short, this means that the indicators in variable 'exercise' of the textbook need no revision based on the judgment made by the English lecturers.

The third variable that is assessed by the English lecturers is variable 'communication'. Unlike the variable 'exercise', this variable 'communication' has 11 (eleven) indicators to be rated. The result of analyzing the data is presented in Table 4.

Table 4. 'Communication' of the Textbook Rated by Eight English Lecturers

\begin{tabular}{|c|c|c|c|c|c|c|c|c|c|c|}
\hline \multirow[t]{2}{*}{ Indicators } & \multicolumn{10}{|c|}{ Lecturers' Scores } \\
\hline & 1 & 2 & 3 & 4 & 5 & 6 & 7 & 8 & Total & Mean \\
\hline $\begin{array}{l}\text { There are opportunities for learners to } \\
\text { communicate with each other, or the } \\
\text { teacher in the target language in } \\
\text { meaningful and authentic situations }\end{array}$ & 4 & 4 & 3 & 4 & 3 & 4 & 4 & 4 & 30 & 3.75 \\
\hline $\begin{array}{l}\text { The opportunities are for learners to } \\
\text { practice interpersonal writing and } \\
\text { speaking balanced throughout the text }\end{array}$ & 3 & 4 & 4 & 4 & 3 & 4 & 4 & 4 & 30 & 3.75 \\
\hline $\begin{array}{l}\text { There are opportunities for learners to } \\
\text { practice presentational writing and } \\
\text { speaking balanced throughout the text }\end{array}$ & 2 & 4 & 2 & 4 & 3 & 4 & 4 & 4 & 27 & 3.40 \\
\hline $\begin{array}{l}\text { The activities include language that is } \\
\text { authentic, accurate and current }\end{array}$ & 3 & 4 & 4 & 4 & 4 & 3 & 4 & 4 & 30 & 3.75 \\
\hline $\begin{array}{l}\text { The communicative activities are set in a } \\
\text { real-world context or represent a real- } \\
\text { world task }\end{array}$ & 4 & 3 & 3 & 4 & 4 & 4 & 4 & 4 & 30 & 3.75 \\
\hline $\begin{array}{l}\text { The activities allow learners to } \\
\text { personalize their responses or provide } \\
\text { their own meaning }\end{array}$ & 3 & 4 & 2 & 2 & 3 & 2 & 4 & 2 & 22 & 2.75 \\
\hline
\end{tabular}


bahasa \& sastra, Vol. 14, No.2, Oktober 2014

\begin{tabular}{|c|c|c|c|c|c|c|c|c|c|c|}
\hline \multirow[t]{2}{*}{ Indicators } & \multicolumn{10}{|c|}{ Lecturers' Scores } \\
\hline & 1 & 2 & 3 & 4 & 5 & 6 & 7 & 8 & Total & Mean \\
\hline $\begin{array}{l}\text { The activities allow learners to provide } \\
\text { their own form and structure(grammar } \\
\text { formation) }\end{array}$ & 2 & 3 & 2 & 2 & 3 & 3 & 3 & 2 & 20 & 2.50 \\
\hline The activities are age-appropriate & 2 & 4 & 2 & 2 & 4 & 2 & 4 & 4 & 24 & 3.00 \\
\hline $\begin{array}{l}\text { The activities are developmentally } \\
\text { appropriate }\end{array}$ & 3 & 4 & 3 & 2 & 3 & 4 & 4 & 4 & 27 & 3.34 \\
\hline $\begin{array}{l}\text { The text and supplemental materials } \\
\text { identify and encourage learners to use } \\
\text { strategies that facilitate communication } \\
\text { and comprehension }\end{array}$ & 4 & 4 & 2 & 4 & 4 & 3 & 4 & 4 & 27 & 3.40 \\
\hline $\begin{array}{l}\text { The activities allow learners to } \\
\text { demonstrate or showcase their } \\
\text { knowledge of and/or skill in using the } \\
\text { target language }\end{array}$ & 3 & 4 & 2 & 4 & 4 & 4 & 4 & 3 & 28 & 3.50 \\
\hline
\end{tabular}

As shown in Table 4, out of 11 (eleven) indicators in variable 'communication', the highest score is 3.75; whereas the lowest one is 2.50 . Specifically, 4 (four) indicators $(36.36 \%)$ is rated at an averaged score of $3.75 ; 1$ (one) variable $(45.45 \%)$ reaches a score of $3.50,3.34,3.00,2.75$, and 2.50 each respectively; and 2 (two) indicators $(18.018 \%)$ are rated at an averaged score of 3.40. Visually the data in variable 'communication' is presented in Figure 4.

\section{Histogram}

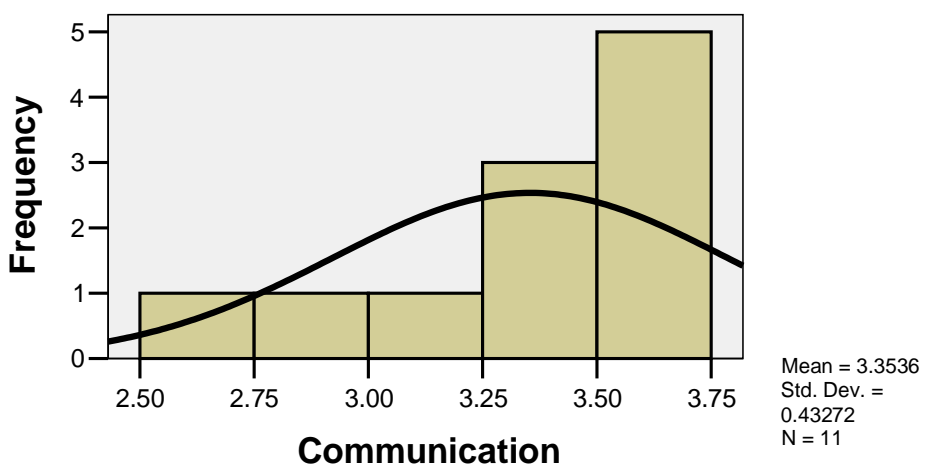

Figure 4. Data Distribution on 'Communication' by the English Lecturers

According to the criteria presented in Table 1 Guideline for Evaluating Indicators of the Textbook, all 11 indicators in variable 'communication' have a score figuring equal or greater than 2.50, which is categorized as 'good' at the minimum. This follows that the indicators in variable 'communication' need no revision according to the criteria in Table 1 Guideline for Evaluating Indicators of the Textbook Developed. 
The variable 'Cultures' constitutes the fourth variable that is assessed by the English lecturers. Unlike the variable 'communication', this variable 'cultures' has 6 (six) indicators to be assessed. The result of the data collection is presented in Table 5 .

Table 5. 'Cultures' of the Textbook Rated by Eight English Lecturers

\begin{tabular}{|c|c|c|c|c|c|c|c|c|c|c|}
\hline \multirow[t]{2}{*}{ Indicators } & \multicolumn{10}{|c|}{ Lecturers' Scores } \\
\hline & 1 & 2 & 3 & 4 & 5 & 6 & 7 & 8 & Total & Mean \\
\hline $\begin{array}{l}\text { There are visual images and cultural } \\
\text { information current and pertinent }\end{array}$ & 4 & 4 & 3 & 4 & 3 & 4 & 4 & 4 & 30 & 3.75 \\
\hline $\begin{array}{l}\text { The visual images and cultural } \\
\text { information are authentic }\end{array}$ & 3 & 4 & 4 & 4 & 3 & 4 & 4 & 4 & 30 & 3.75 \\
\hline $\begin{array}{l}\text { The cultural information is presented in } \\
\text { the target language whenever possible } \\
\text { and/or appropriate }\end{array}$ & 2 & 4 & 2 & 4 & 3 & 4 & 4 & 4 & 27 & 3.40 \\
\hline $\begin{array}{l}\text { The connections between culture and } \\
\text { language are emphasized }\end{array}$ & 3 & 4 & 4 & 4 & 4 & 3 & 4 & 4 & 30 & 3.75 \\
\hline $\begin{array}{l}\text { The text activities are associated with } \\
\text { cultural images and information invite } \\
\text { learner observation, identification, } \\
\text { discussion or analysis of cultural practices, } \\
\text { products, and perspectives }\end{array}$ & 4 & 3 & 3 & 4 & 4 & 4 & 4 & 4 & 30 & 3.75 \\
\hline $\begin{array}{l}\text { The learners are asked to identify, } \\
\text { experience, analyze, produce, or discuss } \\
\text { tangible and expressive products of the } \\
\text { target cultures related with hotel } \\
\text { management matters. }\end{array}$ & 3 & 4 & 2 & 2 & 3 & 2 & 4 & 2 & 22 & 2.75 \\
\hline
\end{tabular}

As shown in Table 5, out of 6 (six) indicators in variable 'cultures', the highest score is 3.75; whereas the lowest one is 2.75 . More specifically, 4 (four) indicators $(66.66 \%)$ is rated at an averaged score of $3.75 ; 1$ (one) variable $(33.33 \%)$ reaches a score of 3.40 , and 2.75 each respectively. Visually, the data in variable 'cultures' are presented in Figure 5.

Histogram

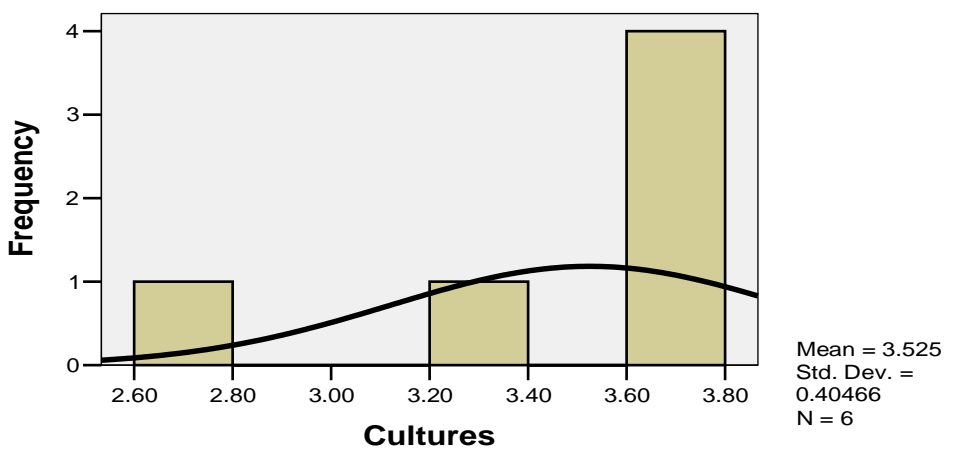

Figure 5. Data Distribution on Variable 'Cultures' by the English Lecturers 
According to the criteria presented in Table 1 Guideline for Evaluating Indicators of the Textbook Developed, all 11 indicators in variable 'cultures' have a score figuring equal or greater than 2.75, which is categorized as above 'good' at the minimum. This follows that the indicators in variable 'cultures' need no revision.
'Connection' makes up the fifth variable that is assessed by the English lecturers. Unlike variable 'cultures', this variable 'cultures' has only 3 (three) indicators to be assessed. The result of the data collection is presented in Table 6.

Table 6. 'Connections' of the Textbook Rated by Eight English Lecturers

\begin{tabular}{|c|c|c|c|c|c|c|c|c|c|c|}
\hline \multirow[t]{2}{*}{ Indicators } & \multicolumn{10}{|c|}{ Scores } \\
\hline & 1 & 2 & 3 & 4 & 5 & 6 & 7 & 8 & Total & Mean \\
\hline $\begin{array}{l}\text { Learners have opportunities to discuss or } \\
\text { discover more about concepts and topics } \\
\text { studied in hotel management matters }\end{array}$ & 4 & 4 & 3 & 4 & 3 & 4 & 4 & 4 & 30 & 3.75 \\
\hline $\begin{array}{l}\text { There are opportunities for learners to } \\
\text { build upon prior personal experiences and } \\
\text { existing background knowledge }\end{array}$ & 3 & 4 & 4 & 4 & 3 & 4 & 4 & 4 & 30 & 3.75 \\
\hline $\begin{array}{l}\text { The concepts, themes, and information } \\
\text { from intended content areas (hotel } \\
\text { management matters) are embedded in or } \\
\text { connected with activities }\end{array}$ & 2 & 4 & 2 & 4 & 3 & 4 & 4 & 4 & 27 & 3.40 \\
\hline
\end{tabular}

As the information in Table 6 indicates, of the 3 (three) indicators in variable 'connection', the highest score is 3.75; whereas the lowest one is 3.40 . More specifically, 2 (two) indicators
$(66.66 \%)$ is rated at an averaged score of $3.75 ; 1$ (one) variable $(33.33 \%)$ reaches a score of 3.40. Visually the data in variable 'connection' is presented in Figure 6.

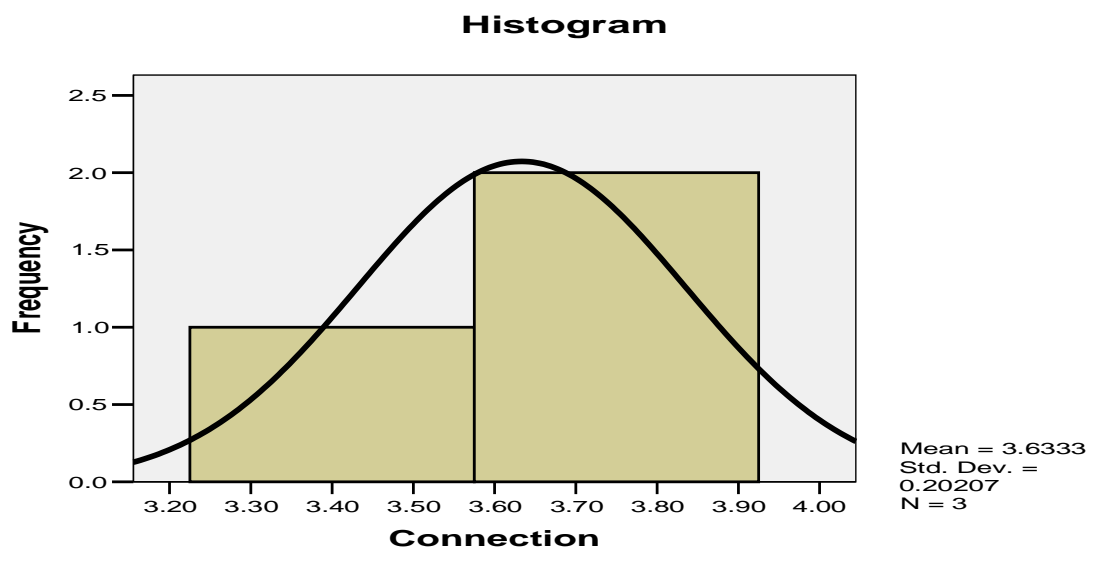

Figure 6. Data Distribution on Variable 'Connection' by the English Lecturers 
According to the criteria presented in Table 1 Guideline for Evaluating Indicators of the Textbook Developed, all 3 indicators in variable 'connection' have a score figuring equal or greater than $3.75(66.66 \%)$, which is categorized as above 'good' at the minimum, and $3.40(33.33 \%)$. This follows that the indicators in variable 'connection' need no revision according to the criteria in Table 1 Guideline for Evaluating Indicators of the Textbook Developed.

The sixth variable that is assessed by the English lecturers is 'communities'. Unlike variable 'connection', this variable 'communities' has 5 (five) indicators to be assessed. The result of the data collection is presented in Table 7 .

Table 7. 'Communities' Rated by Eight English Lecturers

\begin{tabular}{|c|c|c|c|c|c|c|c|c|c|c|}
\hline \multirow[t]{2}{*}{ Indicators } & \multicolumn{10}{|c|}{ Lecturers' Scores } \\
\hline & 1 & 2 & 3 & 4 & 5 & 6 & 7 & 8 & Total & Mean \\
\hline $\begin{array}{l}\text { The text places emphasis on life-long } \\
\text { learning by suggesting uses of the } \\
\text { target language for personal and } \\
\text { professional development? }\end{array}$ & 4 & 4 & 3 & 4 & 3 & 4 & 4 & 4 & 30 & 3.75 \\
\hline $\begin{array}{l}\text { The learners are encouraged to } \\
\text { communicate with others in English, } \\
\text { either face-to-face outside their own } \\
\text { classroom, in conversation, writing, } \\
\text { performances, or presentations }\end{array}$ & 3 & 4 & 4 & 4 & 3 & 4 & 4 & 4 & 30 & 3.75 \\
\hline $\begin{array}{l}\text { The text identifies professions, } \\
\text { careers, or everyday situations which } \\
\text { require or are enhanced by proficiency } \\
\text { in the target language }\end{array}$ & 2 & 4 & 2 & 4 & 3 & 4 & 4 & 4 & 27 & 3.40 \\
\hline $\begin{array}{l}\text { The text presents target } \\
\text { language/culture projects that involve } \\
\text { interacting with members of the local } \\
\text { community or using community } \\
\text { resources }\end{array}$ & 3 & 4 & 4 & 4 & 4 & 3 & 4 & 4 & 30 & 3.75 \\
\hline $\begin{array}{l}\text { The text provides suggestions or } \\
\text { activities that allow learners to } \\
\text { become active participants in bettering } \\
\text { their communities }\end{array}$ & 4 & 3 & 3 & 4 & 4 & 4 & 4 & 4 & 30 & 3.75 \\
\hline
\end{tabular}

As the information in Table 7 indicates, of the 3 (three) indicators in variable 'connection', the highest score is 3.75; whereas the lowest one is 3.40 . More specifically, 4 (four) indicators
$(80 \%)$ is rated at an averaged score of $3.75 ; 1$ (one) variable $(10 \%)$ reaches a score of $3.40(10 \%$.). Visually the data in variable 'connection' can be presented in a histogram shown in Figure 6. 


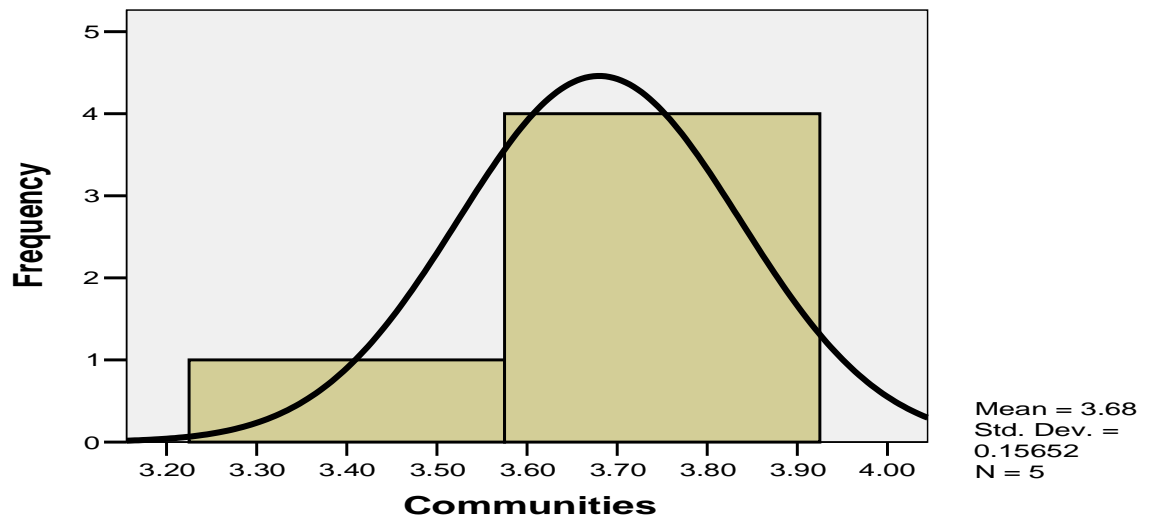

Figure 6. Data Distribution on Variable 'Communities' by the English Lecturers

According to the criteria presented in Table 1 Guideline for Evaluating Indicators of the Textbook Developed, all 3 indicators in variable 'connection' have a score figuring equal or greater than 3.40, which is categorized as above 'good' at the minimum. This follows that the indicators in variable 'connection' need no revision according to the criteria in Table 1 Guideline for Evaluating Indicators of the Textbook Developed.

The last variable that is assessed by the English lecturers is 'general elements'. This last variable has 10 (ten) indicators to be assessed. The result of the data collection is presented in Table 8 .

Table 8. 'General Elements' Rated by Eight English Lecturers

\begin{tabular}{|c|c|c|c|c|c|c|c|c|c|c|}
\hline \multirow[t]{2}{*}{ Indicators } & \multicolumn{10}{|c|}{ Lecturers' Scores } \\
\hline & 1 & 2 & 3 & 4 & 5 & 6 & 7 & 8 & Total & Mean \\
\hline $\begin{array}{l}\text { The language skills are (reading, writing, } \\
\text { listening and speaking) balanced and integrated } \\
\text { within each unit }\end{array}$ & 4 & 4 & 3 & 4 & 3 & 4 & 4 & 4 & 30 & 3.75 \\
\hline $\begin{array}{l}\text { There are opportunities for differentiation and } \\
\text { individual goal-setting }\end{array}$ & 3 & 4 & 4 & 4 & 3 & 4 & 4 & 4 & 30 & 3.75 \\
\hline $\begin{array}{l}\text { The level of the language remains consistent, } \\
\text { developing at an appropriate pace, throughout } \\
\text { the text }\end{array}$ & 2 & 4 & 2 & 4 & 3 & 4 & 4 & 4 & 27 & 3.40 \\
\hline $\begin{array}{l}\text { The activities are plentiful as well as useful } \\
\text { both to the teacher and learner }\end{array}$ & 3 & 4 & 4 & 4 & 4 & 3 & 4 & 4 & 30 & 3.75 \\
\hline $\begin{array}{l}\text { The vocabulary is presented in functional } \\
\text { and/or cultural contexts or clusters }\end{array}$ & 4 & 3 & 3 & 4 & 4 & 4 & 4 & 4 & 30 & 3.75 \\
\hline $\begin{array}{l}\text { The units pertaining grammar are contextually } \\
\text { embedded within the text }\end{array}$ & 3 & 4 & 2 & 2 & 3 & 2 & 4 & 2 & 22 & 2.75 \\
\hline The activities appeal to the learners' interests & 2 & 3 & 2 & 2 & 3 & 3 & 3 & 2 & 20 & 2.50 \\
\hline $\begin{array}{l}\text { Critical thinking skills are promoted or } \\
\text { embedded in activities }\end{array}$ & 2 & 4 & 2 & 2 & 4 & 2 & 4 & 4 & 24 & 3.00 \\
\hline
\end{tabular}




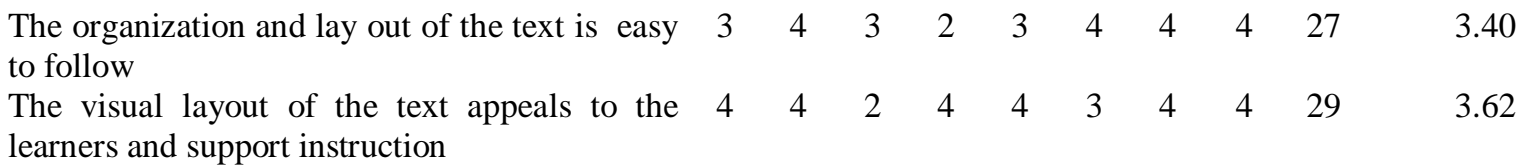

As the information in Table 8 indicates, of the 10 (ten) indicators in variable 'general elements' the highest score is reached at 3.75; whereas the lowest one is 2.50. More specifically, 4 (four) indicators $(40 \%)$ is rated at an averaged score of 3.75 ;
2 (two) indicators $(20 \%)$ are rated at $3.40 ; 1$ (one) variable $(40 \%)$ reaches a score of $3.62,3.00,2.75$, and 2.50 each respectively. Visually the data in variable 'connection' can be presented in a histogram shown in Figure

7.

\section{Histogram}

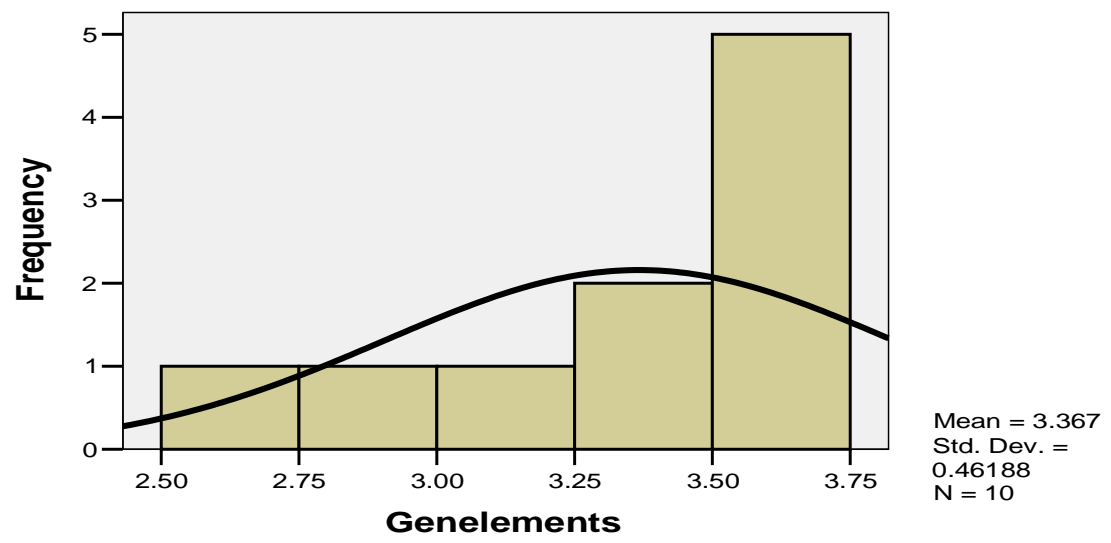

Figure 7. Data Distribution on Variable 'General Elements' by the English Lecturers

According to the criteria presented in Table 1 Guideline for Evaluating Indicators of the Textbook Developed, all 3 indicators in variable 'general elements' have a score figuring equal or greater than 3.40, which is categorized as above 'good' at the minimum. This follows that the indicators in variable 'connection' need no revision according to the criteria in Table 1 Guideline for Evaluating Indicators of the Textbook.

\section{Qualitative Data Collected from the Lecturers}

As has been described previously, there are eight English lecturers that gave the feedback. These 8 (eight) lecturers provided useful feedback indicating the strong points as well as the weak points of the textbook under evaluation. These points are beneficial as the starting points of the revision steps. The weak points that the English lecturers found are as follows: Firsly, the problem of the teaching learning process of English for hotel management may arise especially for the students with low-level English. Next, the textbook has many reading texts and exercises and the English lecturers have to be able to select which topics are suitable with the students' capability. Also, the textbook lacks the presentation of the local culture in the hotel management. Besides, there is no accompanying DVDs or VCDs for listening skills. In addition, there should be a clear explanation in what semester the materials for, how many semesters and how many 
credits for each semester. Finally, the cooperation between English lecturers and the students have an important role in the success of the teaching-learning process.

The strong points that the English lecturers found are summarized briefly as follows: Firsl, the materials are deep, the content is excellent, and it is good, and the materials are representative for English for hotel and industries instruction. Next, the lecturers have to involve to the students world, if it does it helps give learners and critical thinking. Finally, it gives opportunities for learners to communicate with each other and to practice interpersonal writing and speaking. Table 9 presents the qualitative data in the form of feedback of the English lecturers.

Table 9. Qualitative Feedback Provided by English Lecturers

\begin{tabular}{l} 
No $\quad$ Qualitative Feedback \\
\hline a. \\
contextual, and provides sufficient vocabularies in context and students' \\
needs in comprehending and mastering the materials for English for hotel \\
management industries. However, the content will probably be rather difficult \\
for the learners whose English skill is below intermediate level. This textbook \\
I assume is intended for those whose English skill is high-intermediate above. \\
Hence, the problem during teaching and learning process may emerge. As a \\
result, the goals of instruction could be unoptimally achieved (content).
\end{tabular}

b. This textbook presents plenty of exercises, which above all, in the same formats, it is the instructor's responsibility to lessen the student's under pressure, frustration feelings while working on the exercises (exercise).

c. This textbook highlights opportunities for students to practice their oral ability through the exercises given. It is hoped that the instructor can involve all students to be able to speak out their language skill so that not only the smartest outgoing students will surpass their speaking ability (communication).

d. This textbook provides essential connection between the field of study and the career application; as well as the language studied which becomes the students' need. In addition to this, I think it would be more fruitful if the writer provided description of culture of local society too (let's say here, the culture of Malang society)(culture)

e. It's just all right (communities)

f. This book represents appropriate teaching material for ESP, especially English for Hotel management Industries. The writer also endeavours to have the students apply four language skills. In terms of evaluating this textbook, I think it would be better if the writer paid more attention to the lay-out too for example I found the introduction part page is turned over, it has several blue pictures, (since the black and white copy), and it loses page 228. I think this page is important, then it would be better if the writer provided colourful copies to trigger the learners more psychologically in conceiving of the comprehension and understanding for listening skill, why doesn't the instructors present a short video, or recorded (either tapes, VCDs or DVDs) 


\begin{abstract}
No Qualitative Feedback
materials as listening stimulus for additional materials. Above all this textbook is excellent (general elements)

g. Over all, I found this book is very good containing representative materials for English for hotel and industries instruction. It provides essential content, relevant exercises, useful communication approach, sufficient vocabulary in context, close connection among theories, application and cultural elements and stimulates the learner communities to accomplish learning objectives. They are all interrelated. Should I give more suggestion I would say the writer should disclose for what level this textbook is (what semester, what English language skill level) and how many hours the students should follow the lecture. In conclusion this textbook is very good.
\end{abstract}

2. a. Not all units in the materials are easy, specifically chapter1-2 but $75 \%$ of students of semester VI think that it's OK, and they can learn and join the class.

b. After I read Unit1 and Unit 2, based on my opinion this book is good and useful for the students of Semester IV and VI.

3. $\quad a$. The materials are deep. Shouldn't the materials be organized from easy to difficult, so as not to make the lesson tiring? (content)

b. The tasks are varied and enhance the concept presented (exercise)

c. Can teachers finish one unit in one meeting? Shouldn't the exercises be made concise and packed so there is still room for teachers to create on their own? (communication)

d. Overall, pictures should be chosen more carefully. If they are copied, the size should be made bigger and clearer

e. The materials are complete and the tasks are of great variety

4. a. The text in each unit gives more information about hotel management and the learners are active to discuss the topic of each unit (content)

$b$. The instructions in the textbook increase reading comprehension of the students (exercise)

c. The activities build good communication between teacher and students (communication)

d. The language skills are balanced and integrated in each unit and the vocabulary is presented in functional or cultural contexts or clusters

e. This book (English for hotel managers) represents the component of hotel management. The description of each rule in hotel management builds upon prior knowledge and provides opportunities for learners to expand knowledge by emphasizing critical thinking skills. The textbook gives opportunities for learners to communicate with each other and to practice interpersonal writing and speaking

f. I ask permission to you to use these materials for the sixth semester.

5. In general the material is quite good for students of Diploma IV Program. Anyway I think that is a bit harder and too long for the students for Diploma III Program. These students might need shorter materials which can be taught in a session so that they will have a new material in the next levery session.

6. $\quad$ a. Finding the meaning of words will be fine but for pronunciation, I think it will 


No Qualitative Feedback
be more effective if they are drilled since students are mostly not familiar with
phonetic transcription.
b. Page 24: The instruction is confusing I think it should be : "Use the flow
chart suggested below as an example
c. Task 3, page 28: question nos 1 and 2 are actually asking about the same
thing. Unless students are/have been taught about what is meant by the term
"main idea of a piece of writing" they will be trapped in a difficult situation.
d. $\quad$ No clear instruction on which activities are meant for practicing certain
skills, listening, reading, speaking or writing.
e. Needs some reinforcement activities on grammatical points: word building, if
clauses, giving suggestions, showing agreement, asking for opinions.
7. To answer this questionnaire we actually have to rely on the lecturer whether
h. $\quad$ Reading parts are very long and time consuming for students.

Some feedback is obviously positive; other pieces of the feedback are worth considering for the textbook revision.

\section{Presentation of Quantitative Data Collected from the Students}

The aspect to be assessed by the 63 students during the try-out phase in the present study is one variable 'general elements' as that employed in the questionnaire for the subject-matter specialists and the lecturers. This variable has 10 (ten) corresponding indicators in total. The summary of the data is presented in

10.

Table 10. 'General Elements' of the Textbook Rated by Students

\begin{tabular}{|c|c|c|}
\hline Indicator & Total & Mean \\
\hline $\begin{array}{l}\text { The language skills are (reading, writing, listening and speaking) } \\
\text { balanced and integrated within each unit }\end{array}$ & 211 & 3.30 \\
\hline $\begin{array}{l}\text { There are opportunities for differentiation and individual goal- } \\
\text { setting }\end{array}$ & 202 & 3.16 \\
\hline $\begin{array}{l}\text { The level of the language remains consistent, developing at an } \\
\text { appropriate pace, throughout the text }\end{array}$ & 201 & 3.14 \\
\hline $\begin{array}{l}\text { The activities are plentiful as well as useful both to the teacher and } \\
\text { learner }\end{array}$ & 192 & 3.00 \\
\hline $\begin{array}{l}\text { The vocabulary is presented in functional and/or cultural contexts } \\
\text { or clusters }\end{array}$ & 195 & 3.03 \\
\hline $\begin{array}{l}\text { The units pertaining grammar are contextually embedded within } \\
\text { the text }\end{array}$ & 195 & 3.03 \\
\hline The activities appeal to the learners' interests & 201 & 3.14 \\
\hline Critical thinking skills are promoted or embedded in activities & 208 & 3.25 \\
\hline The organization and lay out of the text are easy to follow & 215 & 3.35 \\
\hline $\begin{array}{l}\text { The visual layout of the text appeals to the learners and support } \\
\text { instruction }\end{array}$ & 215 & 3.35 \\
\hline
\end{tabular}


As shown in Table 10, of the 10 (ten) indicators in variable 'general elements' assessed by the students during the try-out phase, the highest score is reached at 3.35; whereas the lowest one is 3.00. More specifically, 2 (two) indicators (20\%) are rated at an averaged score of 3.35; 2 (two) indicators $(20 \%)$ are rated at 3.03; another 2 (two) indicators $(20 \%)$ are rated at 3.14; and 1 (one) variable $(40 \%)$ reaches a score of $3.30,3.25,3.16$, and 3.00 each respectively. Visually, the data in variable 'general elements' are presented in a histogram as shown in Figure

8.

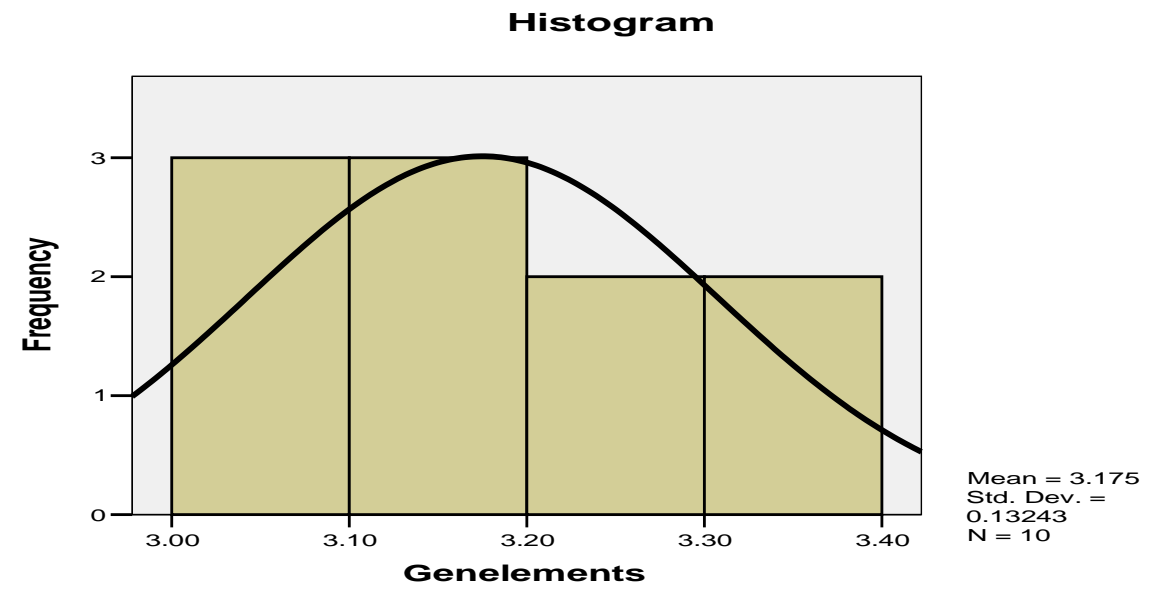

Figure 8. Data Distribution on Variable 'General Elements' by Students

According to the criteria presented in Table 1 Guideline for Evaluating Indicators of the Textbook Developed, all 10 indicators in variable 'general elements' have a score figuring equal or greater than 3.00, which is categorized as 'good' at the minimum. This follows that the indicators in variable 'general elements' need no revision according to the criteria in Table 1 Guideline for Evaluating Indicators of the Textbook Developed.

\section{Qualitative Data Collected from the Students}

There qualitative data from the students are in the form of feedback after they attended the lecturers of English for hotel supervisors. Some of them found some difficulties, some others had difficulties at first, but then could enjoy the materials in the textbook because they already knew some of the contents from other subjects in Bahasa Indonesia in the previous semester, and they felt it was good for they could learn hotel management in English. Therefore, they fully recommended these materials. Also, some students complained of long reading texts and difficult words. Table 11 shows the qualitative data in the form of feedback. 
Table 11. Qualitative Data Provided by Students

\begin{tabular}{l} 
Students' Feedback \\
\hline I. \\
English. These materials are also useful for the resource of my final report later. \\
Many words are not familiar but it's all right after the lecturers explained to me. \\
3. $\quad \begin{array}{l}\text { Some units have very long reading texts, and the time is not enough if it discusses } \\
\text { only in the class. After I got the explanation from the lecturer that I have to read } \\
\text { before because I got the materials before discussion I do understand. The lecturers } \\
\text { explained to me that there are two tasks in credit: structured tasks and } \\
\text { independent tasks that the students have to meet. } \\
\text { Good because I understand the vocabulary and the materials. I already get hotel } \\
\text { management in the previous semester in Bahasa Indonesia and I also have this in } \\
\text { Food and Beverage Management and other hotel subjects, so it's nice that now I } \\
\text { can learn it in English. } \\
\text { Very complicated especially vocabulary, I must read slowly, I always look at the } \\
\text { meaning of new words in the dictionary and it is time consuming. } \\
\text { First I feel it's very difficult, then I connect it with the management hotel I got in } \\
\text { the previous semester in hotel subject, then I feel okey and can join the class. }\end{array}$ \\
5.
\end{tabular}

\section{Qualitative Data Collected from the Hotel Supervisors}

The data collected from the hotel supervisors are essentially triangulation data. The data collected from the hotel supervisors in this phase are summarized in Table 12 as follows.

Table 12. Qualitative Data Provided by the Hotel Supervisors

\begin{tabular}{|c|c|}
\hline & Qualitative Feedback by Hotel Supervisors \\
\hline 1. & The language is not totally so difficult;only in some parts some are difficult \\
\hline 2. & $\begin{array}{l}\text { The content is all right, and it can broaden the knowledge of how to manage the } \\
\text { department in the hotel }\end{array}$ \\
\hline 3. & The materials is suitable for hotel supervisors \\
\hline 4. & I can compare what I do in the workplace and the theory I get from the materials. \\
\hline 5 . & $\begin{array}{l}\text { The theory can give me the direction, the guidance of how I should manage the } \\
\text { hotel department. }\end{array}$ \\
\hline 6. & I really can get knowledge on hotel management. \\
\hline 7. & My knowledge of how general manager works and leads the hotel increases \\
\hline 8. & $\begin{array}{l}\text { I learn a lot of on how hospitality is applied by general manager, supervisor and } \\
\text { staffs in handling guests. }\end{array}$ \\
\hline 9. & $\begin{array}{l}\text { I learn that leader has to direct, participate and support the staffs in working like } \\
\text { Javanese philosophy ing ngarsa sung tulada, ing madya mbangun karsa, tutwuri } \\
\text { handayani. }\end{array}$ \\
\hline 10 . & Some exercises are little bit difficult \\
\hline 11. & $\begin{array}{l}\text { There are hotels with so many employees, but less rooms and hotel with less } \\
\text { employees with many rooms, and hotels with appropriate employees and rooms. }\end{array}$ \\
\hline
\end{tabular}


In general the supervisors involved in the discussion viewed the language used in the textbook was still understandable although in some parts they felt that the language was difficult. Some exercises were also considered difficult. Despite the language complexity and exercises, the supervisors felt that they contents of the book gave them useful knowledge about hotel management matters.

Developing a textbook is a long process that needs a careful study theoretically and empirically. Under Borg and Gall's scheme of R \& D (Borg and Gall, 1989), for instance, at least there are three main cycles a researcher needs to consider, each of which, when exercised carefully, constitutes a research conduct: needs assessment, expert validation, and tryout. Needs assessment, for instance, is essentially a kind of inquiry searching for the needs as seen from conceptual angles as well as from practical sides. It starts with questions about practical needs that require strong theoretical foundations on which to design a product as a consequence (cf. McCawley, 2009). Designing needs assessment together with determining the subjects and instruments to gather relevant data as well as an accurate choice of data analyses is a crucial step from which an idealized concept of an intended product is expected to be generated. In the present study, the textbook developed is a result of empirical and theoretical conceptualization of an ideal textbook for managers in hotel management, particularly in their mastery of English in their context. Idealizing the theoretical framework as a base on which principles of an intended textbook for students as future managers as clients are laid is a critical challenge, an important point also considered by Dahiya and Jha (2011) which Tomlinson (2012) considers it important for development of educational products.
Once a conceptualization is accurately perceived, another challenge is 'translating' ideas in the concept into the intended product. In the present study a good understanding of the hotel world in the managerial level should be present. The present study tries to establish as far as possible the principled development of the textbook suggested by Tomlinson (2012). However, the realization of the principles in the textbook writing is not as easy as how the principles are expressed in statements. For instance, according to Rajan (1997), a good learning material by nature needs to be authentic. If authenticity is meant to be authentic reading passages written by the researcher as the product of the present study requires, the requirement seems to be impossible to be fulfilled. Not only is it linked with time constraints, but also more importantly it is concerned with the degree of genuineness of the content of the passages which is impossible to be fulfilled. It is felt fully that this condition of authenticity will not be satisfactorily met. As a result, adoption of reading passages is inevitable, which according to Tomlinson (2012), is an agreeable situation. Other further challenges are obvious when it comes to designing materials specifically the order of the content of the textbook. What comes first and what next so that it can illustrate $E F H$, then the researcher has to think also the chapters, the objectives, the exercises and the organization of the whole textbook. As what is stated by Tomlinson (2012) introduction to the principles and procedures of materials there are development then is followed by chapters on the application to materials development of approaches based on corpora, near real-life tasks, self-access and new technologies. EFH applies principles and procedures of development, covers tasks with self access. However, it has not yet included 
sophisticated technologies such as an inclusion of audio and/or video materials.

Another point to be discussed is evaluating the textbook. Evaluating instructional materials can be conducted in many ways (Tomlinson, 2012), and one of which is by using world standards. Different procedures to evaluating instructional products outline different emphases. As a result, there will be always mismatches between how the materials are developed and how they may be evaluated. In the present study, the average score for the evaluation from content, exercises, connection, community, cultures, general element reached above the average. By criteria, this means that the elements to be evaluated meet the criteria of the textbook. One of the processes that have been conducted for the evaluation $\mathrm{w}$ as involving the hotel supervisors. It is possible that these hotel supervisors see the materials as a new way which is relevant to the needs of their job, which is different from the one they experienced when they got their college education. However, the evaluation is still limited as it has not included a wider evaluator as and try out from smaller scale to a big scale suggested by Borg and Gall (1989) to include also for instance publishers if the product is intended for a broader market although this may contradict to the report made by Amrani (2011) that publishers seem to limit the use of tryout as their most important means to get feedback as it tends to be costly and consume time and energy. They begin to seek other strategies to obtain feedback.

\section{CONCLUSION}

The textbook evaluated in the present study has been considered meeting the minimum criteria according to World Language Standards 2007, in quantitative terms of fifty three indicators that follow: content, exercises, communication, cultures, connections, communities and general elements as rated by experts, language teachers, and hotel supervisor as well as students. Some qualitative notes, however, are useful feedback to be considered for the betterment of the textbook. All these imply that further work is needed as follow-up actions upon evaluation.

Textbook development carried out in the present study implies methodologically several points that follow. Developing textbook involves many parties and expertise, and evaluation is one of the many processes that should be taken into account. Many steps from needs analysis that covers linguistics and non linguistics aspects are actually to the process of actualization of ideas and continuous evaluation. Researchers of materials development are to comprehend theories, translating theories into practice in the field, to evaluate and seek the new strategies if it does not work in the field, to discuss with expert of language, the specialists and the stakeholders. All activities have to be carried out orderly and systematically.

Getting 'a good score' does not mean the evaluation of the textbook is over. Continuous evaluation seems to be the proper word for materials development. The development of English as a tool for communication, the development of technology, the needs to be the global citizen and other issue of $21^{\text {st }}$ education in the global world are all the sources of evaluation. This can be conducted and arranged systematically since the very beginning process. The best way to be taken into consideration is making a systematical list of evaluation on which step and what evaluation to be made. Therefore a kind of evaluation box is always available in the process for each step to minimize the drawbacks from doing needs analysis, developing the text from concept to transferring ideas. Finally the evaluation is 
still conducted before, in the process, and after publishing the book.

\section{ACKNOWLEDGMENTS}

I would like to express my sincere gratitude to journal Bahasa \& Sastra for publishing this article, and the same goes to those who have helped this research.

\section{REFERENCES}

Amrani, F. (2011). The process of evaluation: A publisher's view. In Tomlinson, B. (ed.) Materials Development in Language Teaching (2nd Edition). Cambridge: Cambridge University Press. pp. 267-295

Aniroh, K. (2009). Developing a Textbook for the Students of Diploma III Program in Hotel Management. Unpublished Desertation. State Univeristy of Malang.

Crawford, J. (2002). The role of materials in the language classroom: Finding the balance in Jack C. Richards and Willy A. Renandya (Eds.) Methodology in Language Teaching: An Anthology of Current Practice. Cambridge: Cambridge University Press, pp. 81-95.

Dahiya, S., \& Jha, A. (2011). Training Needs Assessment: A Critical Study. International Journal of Information Technology and
Knowledge Management.

Volume 4, No. 1, pp. 263-267.

McCawley, P. F. (2009). Methods for Conducting an Educational Needs Assessment: Guidelines for Cooperative Extension System Professionals. Moscow, Idaho: University of Idaho.

Nunan, D.(1988). Principles for Designing Language Teaching Materials. Adelaide: National Curriculum Research Center.

Rajan, B.R. Sundara. (1997). Materials Design (Course 103 Applied Linguistics). Singapore: SEAMEO RELC.

Sierocka, H. (2012). Developing LSP / ESP Materials for Legal Professionals. The University of Bialystok: Poland retrieved from http://fl.uni-mb.si/wpcontent/uploads/2012/10/SIERO CKA. 17 April 2014.

Tomlinson, B. (2012). Materials development for language learning and teaching. Language. Teaching. 45.2, pp. 143-179.

World Language Standard-Based Textbook Evaluation Form 10. 2007. Retrieved from http://www.iflta.org/conference/ conference07/handoutMELNY K5.pdf. January 27, 2008. 